\title{
Hubungan antara Hasil Pemeriksaan Leukosit, Trombosit dan Hematokrit dengan Derajat Klinik DBD pada Pasien Anak Di RSUD Abdul Wahab Sjahranie Samarinda
}

Rosdiana, ${ }^{*}$ William S. Tjeng, ${ }^{* *}$ Sulistiawati Sudarso***

*Fakultas Kedokteran Universitas Mulawarman, **Bagian SMF Anak RSUD Abdul Wahab Sjahranie Samarinda,

*** Laboratorium Ilmu Pendidikan Kedokteran Fakultas Kedokteran Universitas Mulawarman, Samarinda

Latar belakang. Demam berdarah dengue (DBD) dapat menyerang seluruh kelompok usia, khususnya anak-anak sehingga diperlukan perhatian lebih pada derajat klinik maupun hasil laboratorium. Pemeriksaan leukosit, trombosit, dan hematokrit yang akurat untuk setiap derajat klinik DBD akan membantu dan mempermudah diagnosis dan tata kelola pasien untuk menentukan prognosis.

Tujuan. Mengetahui hubungan antara leukosit, trombosit, dan hematokrit dengan derajat klinik DBD.

Metode. Desain penelitian potong lintang data diambil dari catatan rekam medik pasien DBD anak usia $<13$ tahun yang didiagnosis DBD oleh dokter spesialis anak dan dirawat inap di RSUD Abdul Wahab Sjahranie selama tahun 2015. Analisis data menggunakan uji korelasi Spearman dengan menggunakan SPSS 20,0 for Windows.

Hasil. Didapatkan 95 responden yang memenuhi kriteria penelitian. Hasil uji analisis didapatkan hubungan positif tidak bermakna dan sangat lemah antara jumlah leukosit dan derajat klinik DBD ( $\mathrm{p}=0,439 ; \mathrm{r}=0,080)$. Terdapat hubungan negatif yang bermakna sedang antara jumlah trombosit dengan derajat klinik DBD ( $\mathrm{p}=0,000 ; \mathrm{r}=-0,449)$, dan terdapat hubungan positif bermakna dan lemah antara hematokrit dengan derajat klinik DBD ( $p=0,038 ; r=0,214)$.

Kesimpulan. Tidak terdapat hubungan bermakna antara jumlah leukosit dengan derajat klinik DBD, dan terdapat hubungan bermakna antara jumlah trombosit dan nilai hematokrit dengan derajat klinik DBD. Sari Pediatri 2017;19(1):41-5

Kata kunci: leukosit, trombosit, dan hematokrit, derajat klinik DBD

\section{Correlation between Leucocyt, Platelet Count, and Hematocrit Value with Clinical Degree of DHF in Pediatric Patients in RSUD Abdul Wahab Sjahranie Samarinda}

Rosdiana, ${ }^{*}$ William S. Tjeng, ${ }^{* *}$ Sulistiawati Sudarso***

Background. Dengue haemorhagic fever their can affect all age groups, especially at young age patients. Clinical degree of DHF and laboratory results need more attention in this age group. The definite value of blood test for each clinical degree of DHF is expected to help and make it easier, but also to give proper treatment based on patient's clinical degree and determine the prognosis.

Objective. To determine the correlation between leukocyte count, platelet count, and hematocrit value with clinical degree of DHF. Methods. This research is an observational research with cross sectional design. Data are based on medical records of pediatric patients under 13 years old who were diagnosed with DHF by pediatrician and were hospitalized in RSUD Abdul Wahab Sjahranie Samarinda in 2015. The statistical analysis use frequency distribution analysis and hypothesis test using Spearman Correlation using SPSS 20.0 for Windows computer program.

Results. 95 respondens were included in this research. Bivariate analysis by Spearman correlation test indicates a weak numerical value with positive sign and no significant correlation between leukocyte count and clinical degree of DHF ( $p=0.439 ; \mathrm{r}=0.080)$. There is a significant correlation between platelet count with clinical degree of DHF with negative sign and moderate value ( $\mathrm{p}=0.000$; $\mathrm{r}=-$ $0.449)$. And there is a significant correlation with weak but positive correlation between the value of hematocrit with clinical degree of DHF ( $\mathrm{p}=0.038 ; \mathrm{r}=0.214)$.

Conclusions. There is no significant correlation between leukocyte count and clinical degree of DHF, and there is a significant correlation between platelet count and hematocrit with clinical degree of DHF. Sari Pediatri 2017;19(1):41-5

Keywords: leukocyte, platelet, hematocrit, clinical degree of DHF

Alamat korespondensi: Rosdiana. Fakultas Kedokteran Universitas Mulawarman Jl.Kerayan, Kampus Gn. Kelua, Samarinda 75119.

E-mail: idrisrosdiana@yahoo.com 
Rosdiana dkk: Hubungan antara leukosit, trombosit dan hematokrit dengan derajat klinik DBD

$\mathrm{D}$ emam berdarah dengue (DBD) merupakan penyakit infeksi virus dengue yang ditularkan melalui gigitan nyamuk aedes aegypti dan aedes albopictus dengan manifestasi klinis yang bervariasi dari paling ringan sampai berat yang disertai syok. ${ }^{1}$ Infeksi virus dengue ini menyebabkan 100 juta kasus demam akut dan 500 ribu kasus berat, yaitu DBD dan SSD (sindrom syok dengue) dengan 22.000 kasus kematian, sebagian besar di antaranya anak di bawah 15 tahun. $^{2}$

Morbiditas dan mortalitas anak yang terjangkit DBD cenderung meningkat sehingga diperlukan perhatian lebih, baik pada derajat klinik maupun hasil laboratorium. ${ }^{3}$ Pada awal demam, leukopenia menjadi penanda terjadinya suatu infeksi virus. ${ }^{4}$ Trombositopenia menggambarkan ada tidaknya disfungsi pembekuan darah, sedangkan jumlah hematokrit menggambarkan permeabilitas vaskular. ${ }^{5}$

Dari hasil pemeriksaan laboratorium rutin, abnormalitas hematologi umum yang didapat adalah leukopenia ringan sampai leukositosis sedang, trombositopenia, dan nilai hematokrit yang normal atau meningkat. ${ }^{6}$ Hasil pemeriksaan hematologi akan sangat bermanfaat jika terdapat suatu parameter laboratorium tertentu yang dapat memperkirakan perjalanan penyakit DBD sehingga kasus tersebut dapat diberikan perhatian lebih. Pemeriksaan hematologi ini dapat dilakukan di berbagai laboratorium, bahkan di Puskesmas. ${ }^{7}$

Perjalanan penyakit DBD sulit diramalkan. Beberapa penelitian ditemukan secara klinis dan laboratorium tampak tidak berat, tetapi dalam perjalanan penyakitnya mendadak syok (SSD; derajat 3 dan 4) dan pada beberapa kasus berakhir dengan kematian. ${ }^{8}$ Badan kesehatan dunia WHO SEARO merekomendasikan kriteria derajat klinik DBD untuk mempermudah pemberian terapi dan mencegah agar pasien dengan derajat klinik 1 dan 2 tidak menjadi lebih parah dan masuk menjadi derajat klinik 3 dan 4. ${ }^{9,10}$

Namun, kriteria derajat klinik tersebut tidak mencantumkan nilai yang pasti dari hasil pemeriksaan leukosit, trombosit, dan hematokrit. ${ }^{11}$ Oleh karena itu, penelitian ini dilakukan bertujuan untuk mengetahui hubungan antara jumlah leukosit, trombosit, dan hematokrit dengan derajat klinik DBD pada pasien anak di RSUD Abdul Wahab Sjahranie Samarinda. Diharapkan, hal tersebut dapat membantu petugas medis memperkirakan derajat klinik diagnosis DBD sehingga penanganan dapat lebih maksimal dengan pemeriksaan darah yang akurat untuk setiap derajat klinik DBD.?

\section{Metode}

Penelitian desain potong lintang digunakan untuk mengetahui hubungan antara leukosit, trombosit, dan hematokrit dengan derajat klinik DBD. Data diambil dari catatan rekam medik pasien DBD anak usia $<13$ tahun yang diagnosis oleh dokter spesialis anak. Data rekam medik yang dipakai adalah data pasien DBD yang dirawat inap di RSUD Abdul Wahab Sjahranie selama tahun 2015 dengan dilengkapi hasil pemeriksaan leukosit, trombosit dan hematokrit saat pertama kali masuk rumah sakit. Data rekam medik yang tidak dilengkapi hasil laboratorium saat pertama kali masuk rumah sakit tidak dimasukkan dalam penelitian. Analisis data menggunakan uji korelasi Spearman dengan menggunakan SPSS 20,0 for Windows.

\section{Hasil}

Dari hasil perhitungan besar sampel SEARO 2011 selama tahun 2015, didapatkan sampel minimal 95 pasien DBD anak yang memenuhi kriteria penelitian. Pada Tabel 1 Distribusi kelompok usia terbanyak 4-8 tahun, yaitu 39 anak (41,1\%), pasien perempuan lebih banyak 54 (56,8\%) dari laki-laki 41 (43,2\%) dengan perbandingan 1;1,3. Derajat klinik pasien DBD anak paling banyak didapatkan pada derajat klinik satu 56 $(58,9 \%)$, dan paling sedikit pada derajat klinik empat $5(5,3 \%)$.

Korelasi positif tidak bermakna antara leukosit dan derajat klinik DBD dengan kekuatan hubungan sangat lemah $(p=0,439 ; r=0,080)$. Berarti semakin tinggi jumlah leukosit maka semakin berat derajat klinisnya. Namun, hal ini hanya terlihat pada derajat 1 hingga derajat 3. Pada derajat 4 mengalami sedikit penurunan. Korelasi negatif bermakna antara trombosit dan derajat klinik DBD dengan kekuatan hubungan sedang ( $\mathrm{p}=0,000 ; \mathrm{r}=-0,449)$. Berarti semakin rendah jumlah trombosit maka semakin berat derajat klinisnya. Korelasi positif bermakna antara hematokrit dan derajat klinik DBD dengan kekuatan hubungan lemah $(\mathrm{p}=0.038 ; \mathrm{r}=0.214)$. Berarti semakin tinggi jumlah hematokrit maka semakin berat derajat 
Rosdiana dkk: Hubungan antara leukosit, trombosit dan hematokrit dengan derajat klinik DBD

Tabel 1. Karakteristik sampel pasien DBD

\begin{tabular}{lc}
\hline Karakteristik sampel & Jumlah (\%) \\
\hline Usia (tahun) & \\
$0-3$ & $28(29,5)$ \\
$4-8$ & $39(41,1)$ \\
$9-12$ & $28(29,5)$ \\
Jenis kelamin & \\
Perempuan & $54(56,8)$ \\
Laki-laki & $41(43,2)$ \\
Derajat Klinik DBD & \\
Derajat 1 & $56(58,9)$ \\
Derajat 2 & $26(27,4)$ \\
Derajat 3 & $8(8,4)$ \\
Derajat 4 & $5(5,3)$ \\
\hline
\end{tabular}

klinisnya. Namun, hal ini hanya terlihat pada derajat 1 hingga derajat 3 . Pada derajat 4 mengalami sedikit penurunan (Tabel 2).

\section{Pembahasan}

Kelompok usia terbanyak pada penelitian ini 4-8 tahun 39 (41,1\%), tidak berbeda jauh dengan penelitian Hartoyo $^{12}$ di RSUD Ulin Banjarmasin dengan kelompok usia 5-10 tahun. Demikian juga dengan penelitian Mayyeti ${ }^{13}$ di RS DR. M. Djamil Padang yang melaporkan kejadian syok yang tinggi pada kelompok usia 5-10 tahun. Berdasarkan distribusi jenis kelamin didapatkan penyakit DBD lebih banyak terjadi pada perempuan 54 (56,8\%) dengan perbandingan $1: 1,3$. Hal tersebut sesuai dengan penelitian Hukom $\mathrm{dkk}^{14}$ di RSUP Prof. Dr. R. D. Kandou Manado bahwa pasien DBD anak perempuan lebih banyak dibandingkan laki-laki, yaitu berjumlah 33 anak dengan perbandingan 1:1,3.

Kejadian DBD pada anak usia muda karena faktor daya tahan tubuh yang belum sempurna bila dibandingkan pada dewasa. Anak berisiko lebih tinggi terkena penyakit termasuk yang disebabkan oleh virus dengue. Perbedaan usia yang didapat mungkin karena kebiasaan nyamuk yang aktif menggigit di siang hari, pada jam tersebut anak bermain di luar rumah. ${ }^{12}$ Pengaturan transmisi penyakit DBD yang terjadi saat ini didapatkan telah bergeser ke fasilitas umum, seperti sekolah, masjid, gereja, dan tempat bermain anak. ${ }^{15}$ Dari hasil korelasi leukosit dan derajat klinik DBD,
Tabel 1. Korelasi antara jumlah leukosit, trombosit, dan hematokrit

\begin{tabular}{lccc}
\hline Derajat & \multicolumn{3}{c}{ Jumlah leukosit $\left(/ \mathrm{mm}^{3}\right)$} \\
\cline { 2 - 4 } Klinik & Rerata & SB & Uji Spearman \\
DBD & \multicolumn{4}{c}{2944,7} & $\mathrm{p}=0,439$ \\
\hline 1 & 4651,6 & 3317,8 & \\
2 & 5237,3 & $\mathrm{r}=0,080$ \\
3 & 6587,5 & 3503,6 & \\
4 & 5874 & 5661,1 & $\mathrm{p}=0,000$ \\
\hline \multicolumn{4}{c}{ Jumlah trombosit $\left(/ \mathrm{mm}^{3}\right)$} \\
\hline 1 & 105160,7 & 56100,8 & \\
2 & 81653,8 & 85098,9 & $\mathrm{r}=-0,449$ \\
3 & 59000 & 58782,8 & \\
4 & 35200 & 17711,5 & $\mathrm{p}=0,038$ \\
\hline \multicolumn{4}{c}{ Jumlah hematokrit $\left(/ \mathrm{mm}^{3}\right)$} \\
\hline 1 & 36,60 & 4,10 & $\mathrm{r}=0,214$ \\
2 & 38,45 & 5,04 & \\
3 & 40,62 & 5,36 & \\
4 & 38,20 & 4,20 & \\
\hline
\end{tabular}

rerata jumlah leukosit 4651,6 pada derajat 1 dan mengalami peningkatan jumlah menjadi 6587,5 pada derajat 3, kemudian menurun menjadi 5874 pada derajat 4. Rerata jumlah leukosit yang didapat pada setiap derajat klinik masih dalam jumlah normal. Hal tersebut kemungkinan karena RSUD Abdul Wahab Sjahranie merupakan rumah sakit rujukan utama di Samarinda sehingga pasien yang datang berobat kebanyakan tidak pada hari pertama demam melainkan pada hari ke-4 dan ke-5 demam. Hasil tersebut didukung oleh penelitian Dewi $\mathrm{dkk}^{16}$ di RS Cipto Mangunkusumo yang melaporkan hubungan tidak bermakna antara leukosit dan SSD, tetapi risiko terjadinya SSD pada leukopenia lebih rendah dari yang tidak leukopenia.

Pada kepustakaan yang ada, hari pertama hingga ke-3 demam biasanya ditemukan leukopenia dengan hitung jenis yang masih dalam batas normal. Leukopenia terjadi karena depresi sumsung tulang akibat proses infeksi virus secara langsung ataupun karena mekanisme tidak langsung melalui produksi sitokin proinflamasi yang menekan sumsum tulang. ${ }^{5,17}$ Pada syok berat dapat dijumpai leukositosis dengan ditandai adanya limfosit yang bertransformasi atipik atau disebut juga limfosit plasma biru (LPB) yang cukup banyak dan ditemukan neutropenia absolut. ${ }^{18}$ 
Hal tersebut karena pada SSD (derajat 3 dan 4) monosit yang terinfeksi virus lebih banyak mengakibatkan sel limfosit berdiferensiasi menjadi limfosit atipik. ${ }^{6}$

Dari hasil korelasi trombosit dan derajat klinik DBD didapatkan rerata jumlah trombosit yang semakin menurun pada setiap peningkatan derajat klinik DBD. Penelitian ini sesuai dengan penelitian yang dilakukan badan litbang kesehatan di lima RSUD Jakarta yang menyatakan bahwa trombosit berhubungan dengan derajat DBD. ${ }^{19}$ Selain itu, penelitian yang dilakukan Valentino' di RSUP Dr. Kariadi Semarang juga melaporkan bahwa semakin rendah jumlah trombosit maka semakin parah derajat kliniknya.

Hal tersebut dapat terjadi akibat sumsum tulang pada hari ke- 4 mengalami hiposelular dengan hambatan pada semua sistem hemopoesis sehingga menyebabkan penurunan trombosit pada DBD. ${ }^{5}$ Penurunan trombosit diduga karena trombopoesis yang menurun, destruksi trombosit dalam darah meningkat, serta gangguan fungsi trombosit. Ditemukannya kompleks imun pada permukaan trombosit diduga sebagai penyebab agregasi trombosit yang kemudian akan dimusnahkan oleh retikuloendotelial sistem. ${ }^{20}$ Ketika jumlah trombosit $<100.000 / \mathrm{mm}^{3}$, fungsi trombosit dalam hemostasis terganggu sehingga integritas vaskular berkurang dan menyebabkan kerusakan vaskular. Kemudian muncul manifestasi perdarahan yang dapat menyebabkan syok dan memperberat derajat DBD. ${ }^{21}$

Hasil korelasi hematokrit dan derajat klinik DBD memperlihatkan nilai hematokrit pada derajat 1 meningkat pada derajat 3 , dan pada derajat 4 nilai rerata menurun. Kejadian tersebut kemungkinan terdapat perdarahan atau anemia sehingga jumlah eritrosit rendah dan memengaruhi nilai hematokrit menjadi rendah atau bahkan normal. Ukuran eritrosit juga dapat memengaruhi viskositas darah. Jika ukuran eritrosit kecil maka viskositas darah rendah sehingga bisa memengaruhi hematokrit. ${ }^{7,19}$

Hemokonsentrasi dengan peningkatan hematokrit $\geq 20 \%$ merupakan salah satu kriteria laboratorium yang dikeluarkan WHO. Hal tersebut mencerminkan peningkatan permeabilitas kapiler dan perembesan plasma. Akibat kebocoran ini, volume plasma berkurang dan sel darah merah banyak di dalam pembuluh darah sehingga mengakibatkan syok hipovolemik dan kegagalan sirkulasi. Syok hipovolemik yang terjadi dapat memperburuk derajat DBD., ${ }^{7,19}$

\section{Kesimpulan}

Tidak terdapat hubungan antara jumlah leukosit dengan derajat klinik DBD. Terdapat hubungan antara jumlah trombosit dan nilai hematokrit dengan derajat klinik DBD. Hal ini berarti bahwa semakin rendah jumlah trombosit maka semakin berat derajat klinik DBD dan semakin tinggi nilai hematokrit maka semakin berat derajat klinik DBD.

\section{Daftar pustaka}

1. IDAI. Buku ajar infeksi dan pediatri tropis. Edisi ke-2. Jakarta: Badan Penerbit Ikatan Dokter Anak Indonesia; 2015.

2. Centers for Disease Control and Prevention. Epidemiology of Dengue. U.S Department of Health \& Human Services: 2014.

3. Patandianan R, Mantik MF, Manoppo F, Mongan A. E. Hubungan Kadar Hemoglobin Dengan Jumlah Trombosit Pada Pasien Demam Berdarah Dengue. Jurnal e-Biomedik (eBM) 2013;1:868-72.

4. Risniati Y, Tarigan LH, Tjitra E. Leukopenia sebagai prediktor terjadinya sindrom syok dengue pada anak dengan demam berdarah dengue di RSPI. Prof. Dr. Sulianti Saroso. Jakarta: Media Litbang Kesehatan 2011;21:96-103.

5. Widyanti NN. Hubungan jumlah hematokrit dan trombosit dengan tingkat keparahan pasien demam berdarah dengue di rumah sakit Sanglah tahun 2013-2014. E-Jurnal Medika 2016;51-6.

6. Handoko D, Prasetyowati EB, Hartoyo S. Modul pengendalian demam berdarah dengue. Jakarta: Kementerian Kesehatan Republik Indonesia Direktorat Jenderal Pengendalian Penyakit Dan Penyehatan Lingkungan; 2011.

7. Tanjung AH, Nurnaningsih, Laksono IS. Jumlah leukosit, neutrofil, limfosit, dan monosit sebagai prediktor infeksi dengue pada anak dengan gizi baik di fasilitas kesehatan dengan sumber daya terbatas. Sari Pediatri 2015;17:175-9.

8. Gunawan S, Sutanto FC, NN Tatura S, Mantik MF. Platelet distribution width dan mean platelet volume: hubungan dengan derajat penyakit demam berdarah dengue. Sari Pediatri 2010;12:74-7.

9. Valentino B. Hubungan antara hasil pemeriksaan darah lengkap dengan derajat klinik infeksi dengue pada pasien dewasa Di RSUP Dr. Kariadi Semarang [KTI strata 1]. Semarang: Fakultas Kedokteran UNDIP; 2012.

10. WHO SEARO. Comprehensive guidelines for prevention and control of dengue and dengue hemorrhagic fever. Geneva: 
World Health Organization; 2011.

11. Syumarta Y, Hanif AM, Rustam E. Hubungan jumlah trombosit, hematokrit dan hemoglobin dengan derajat klinik demam berdarah dengue pada pasien dewasa di RSUP. M. Djamil Padang. Kesehatan Andalas 2014;3:492-8.

12. Hartoyo E. Spektrum klinis demam berdarah dengue pada anak. Sari Pediatri 2008;10:145-50.

13. Mayyeti. Hubungan gambaran klinis dan laboratorium sebagai faktor risiko syok pada demam berdarah dengue. Sari Pediatri 2010;11:367-73.

14. Hukom AO, Warouw SM, Memah M, Mongan, AE. Hubungan nilai hematokrit dan nilai jumlah trombosit pada pasien demam berdarah dengue. Jurnal e-Biomedik (eBM) 2013;1:707-11.

15. Heatubun CE, UmbohA, Mongan AE, Manoppo F. Perbandingan jumlah trombosit pada demam berdarah dengue tanpa syok dan syok di RSUP Prof. Dr. R. D. Kandou Manado. Jurnal e-Biomedik (eBM) 2013;1:863-7.

16. Dewi R, Tumbelaka AR, Sjarif DR. Clinical features of dengue hemorrhagic fever and risk factors of shock event. Paediatrica Indonesiana 2006;46:144-8.

17. Masihor JJ, Mantik MF, Memah M, Mongan A E. Hubungan jumlah trombosit dan jumlah leukosit pada pasien anak demam berdarah dengue. Jurnal e-Biomedik (eBM) 2013;1:391-5.

18. Chastity RS, Suryanto. Hubungan jumlah sel limfosit dengan derajat klinis pada pasien DHF. Yogyakarta: Universitas Muhammadiyah Yogyakarta, 2010.

19. Avrina DR, Hasanah DS, Sulistiowati DE. Karakteristik penderita demam berdarah dengue (DBD) di lima RSUD Jakarta, tahun 2010. pusat teknologi terapan kesehatan dan epidemiologik klinik, badan litbang kesehatan. Jakarta: Kementerian Kesehatan;2011.

20. Elindra F, Achmad S, Tejasari M. Hubungan kadar trombosit dan hematokrit dengan derajat penyakit demam berdarah dengue pada pasien dewasa. Bandung: Prosiding Penelitian Sivitas Akademik UNISBA (Kesehatan) 2014:492-98. Diakses tanggal 18-7-2017. Didapat dari: http://karyailmiah.unisba. ac.id/index.php/dokter/article/view/1046.

21. Fitriastri NH, Nilapsari R, Kusmiati M. Hubungan trombositopenia dengan manifestasi klinis perdarahan pada pasien demam berdarah dengue anak. Bandung: Prosiding Pendidikan Dokter 2014:10-16. Diakses tanggal 18-7-2017. Didapat dari: http://karyailmiah.unisba.ac.id/index.php/dokter/ article/view/1046. 